\title{
Queerifierad antropologi med potential att utveckla queerteorin
}

Boyce, Paul, Gonzalez-Polledo E. J. och Posocco, Silvia (red.). 2020. Queering Knowledge: Analytics, Devices and Investments after Marilyn Strathern. London och New York: Routledge. (208 sidor)

NÄR JAG VAR student, och senare doktorand, i socialantropologi vid Stockholms universitet var det bland annat Marilyn Stratherns texter som formade mitt antropologiska tänkande. Strathern visade att vi behöver analysera vår empiri på tvärs, från olika vinklar, och använda flera perspektiv för att kunna göra en komplex analys - ändå kommer våra analyser aldrig att vara fullständiga. Att sträva efter fullständiga analyser var nog inte heller Stratherns mål. Empiri kan nämligen, enligt Strathern, sättas samman på en mängd olika sätt. Etnografisk forskning innebär att vi gör partiella sammanlänkningar av objekt, symboler och relationer som lika gärna hade kunnat göras på andra sätt. För Strathern är vår framställning av empirin lika viktig som hur vi tolkar och presenterar den. Under läsningen av antologin Queering Knowledge: Analytics, Devices and Investments after Marilyn Strathern framstår det som självklart att Stratherns teoribildning på ett utomordentligt sätt kan länkas samman med queerteori.

(C) The authors. Published by Föreningen Lambda Nordica under the CC BY-ND license. 
Antologin är indelad i tio kapitel som tar sin utgångspunkt i antropologi som disciplin och hur kunskapsprocesser kan queerifieras i fråga om form, objekt, relationer och analyser. Redaktörerna för antologin har - $\mathrm{i}$ Stratherns anda - velat att analyserna i de olika kapitlen ska variera till form och ge läsaren möjlighet att själv tänka vidare, bortom texten. Kapitlen rör sig över olika platser, identiteter, släktskapsformer, politiska situationer och teoretiska analyser. Det gemensamma för kapitlen är att författarna på ett insiktsfullt sätt bearbetar Stratherns teorier queerteoretiskt - och samtidigt queerfierar antropologin. I en recension av en så komplex, tät och mångfasetterad bok som denna är det inte möjligt att göra en djupare genomgång av samtliga kapitel. Jag kommer därför, utöver bokens generella vetenskapliga bidrag, att koncentrera min analys till några av de kapitel som explicit fokuserar på den teoretiska sammanlänkningen av antropologi och queerteori i syfte att lyfta fram vad vi som queerteoretiker kan lära av antologin.

Irene Peano länkar i sitt kapitel samman Marilyn Stratherns och Judith Butlers teorier. Hon använder Donna Haraways teori om cyborgen som position och metod för att överbrygga likheter och skillnader mellan Strathern och Butler. Samläsningen av Strathern och Butler via Haraway utgör i sig ett exempel på det som Strathern kallar för en partiell förbindelse: en förbindelse där vi sätter samman och plockar isär vår empiri på oväntade sätt. Peano tar oss med på ett experimentellt utforskande där Strathern och Butler sätts samman till en expanderad kropp av tankar som analyseras. Peanos kapitel är det som inspirerar mig mest och får mig att tänka bortom det redan tänkta på nya sätt. Peano framhåller hur såväl Strathern som Butler lärt oss att vara radikala utan att förutsätta förutbestämda identiteter. Stratherns teori om att vi inte är individer (individuals), utan snarare "dividualer" (dividu$a l s$ ) - formade av så många olika influenser och sociala interaktioner att vi omöjligen kan betraktas som separata individer - tillämpas här på ett självklart sätt. Inom det queera fältet återfinns också teorier om hur vårt tillblivande som subjekt/individer är både föränderligt och kontextberoende. Detta, om något, blir en intressant utmaning för alla oss som forskar inom queerteoretiska fält: hur kan vi förstå, skapa 
kunskap och skriva om genus och sexualitet bortom det västerländska individualistiska synsättet?

Kapitelförfattarna Annelin Eriksen och Christine M. Jacobsen gör en samläsning av Marilyn Strathern och Judith Butler för att hitta vägar bort från att framställa empiri som skillnader som utgår från givna (västerländska) premisser. De utgår från den queera potentialen i den ontologiska vändningen inom antropologin. Vändningen bygger på ett ifrågasättande av kulturbegreppet och öppnar upp för skillnader oberoende av sort. Flera av antologins författare framhåller Strathern som en föregångare i fråga om den ontologiska vändningen och lyfter fram hennes sätt att sätta samman empiri, skapa analytiska begrepp, utmana metodologiskt och ifrågasätta antropologins fokus på framställningen av dem vi beforskar med hjälp av västerländska begrepp. Kategorier är något som Strathern tidigt pekade ut som hinder för kunskap. Såväl den antropologiska som den queera forskningen behöver se bortom de kategoriseringar vi tar för givna, även avseende genus och sexualitet. I antologins inledning skriver redaktörerna att den queera forskningen riskerar att klassificera sina objekt som queera även när denna definition inte stämmer med hur informanterna själva skulle beskriva sina liv och sin identitet. Genom att förhålla oss öppet till hur informanter beskriver sig själva och sina liv, ökar våra förutsättningar att beskriva dem vi forskar om på ett sätt som är i samklang med deras egna definitioner.

E. J. Gonzalez-Polledo sammanför Stratherns teorier om genus med transteori och teorier om kroppslighet och försöker på så sätt tänka bortom genus. Utifrån sitt fältarbete i Melanesien drog Strathern slutsatsen att genus inte går att analysera på ett enkelt sätt. Genus är mångfaldigt och att tänka sig genus som en specifik form begränsar analysen. Gonzalez-Polledo lyfter därför frågan om hur genus går att använda om vi - i Strathernsk mening - tänker oss det som en relationell kapacitet. Att tänka bortom genus innebär, enligt Gonzalez-Polledo, just att tänka bortom specifika former och uttryck och att istället låta mångfald stå i centrum. I det här kapitlet, som i flera andra, utmanas vår benägenhet att ta hur genus görs och tar sig form för givna. Gonzalez-Polledo berör den utopiska potentialen i transstudier och kanske är det just utopiska 
tankegångar vi behöver för att kunna tänka bortom de kunskapsprocesser vi är delaktiga i.

Antologin i sin helhet synliggör hur queerteori och antropologisk teori tillsammans kan skapa mångfaldiga sätt att ta sig an etnografiska material och undersöka skillnader med öppet sinne. En brist hos antologin är att den till viss del följer den sedvanliga antropologiska riktningen; den talar till västerländska forskare som forskar om "de andra". Att kritiskt granska de begrepp och forskningsprocesser som används i en för forskaren välkänd miljö är lika viktigt som att inte överföra västerländska begrepp till en plats där dessa framstår som irrelevanta. Den viktigaste insikten jag bär med mig från antologin är betydelsen av att utmana och transformera såväl queerteori som antropologisk teori. Antologin öppnar upp för queerifierad antropologi och Strathernsk queerteori, även om den måhända är allt för investerad i Stratherns teorier och begrepp för att tilltala de queerteoretiska forskare som inte är inlästa på antropologi. 